\title{
The rocky path from policy-relevant science to policy implementation - a case study from the South American Chaco
}

\author{
Daniel M. Cáceres ${ }^{1}$, Felicitas Silvetti ${ }^{2}$ Sandra Díaz ${ }^{3}$
}
${ }^{1}$ Facultad de Ciencias Agropecuarias, Universidad Nacional de Córdoba (UNC) and Consejo Nacional de Investigaciones Científicas (CONICET). Avenida Valparaíso s/n, X5.000, Córdoba, Argentina.
${ }^{2}$ Facultad de Ciencias Agropecuarias, Universidad Nacional de Córdoba (UNC). Avenida Valparaíso s/n, X5.000, Córdoba, Argentina.
${ }^{3}$ Instituto Multidisciplinario de Biología Vegetal (IMBIV-CONICET) and Departamento de Diversidad Biológica y Ecología, FCEFyN, Universidad Nacional de Córdoba, Vélez Sársfield 1611, CC 495, X5000ZAA, Córdoba, Argentina.

Corresponding author: Cáceres, Daniel M. (dcaceres@agro.unc.edu.ar) Telephone/fax: +54 3514644990 


\begin{abstract}
Why does co-produced, policy-relevant, adequately communicated science fail to influence policy implementation? Analysts of the science-policy interface often focus on the societal relevance of the research questions and on the strategies to convey findings to the political sphere. We argue that these conditions are necessary but not sufficient. We analyze a case study from Argentina, the process leading to the Córdoba Provincial Law for the Protection of Native Forests, in the light of two contrasting models of the science-policy interface: the Information Deficit and the Power Dynamics models, and conclude that the second better describes the process. We propose some broad conditions that should influence the likelihood of a piece of scientific knowledge to be incorporated into environmental policy implementation.
\end{abstract}

\title{
Introduction
}

Controversies on the role of science in society, dating far back [1-5], have now regained momentum in the face of the formidable ecological and sustainability challenges of the 21th century [6-9]. There is a vast and heterogeneous corpus of literature on the sciencepolicy interface, and more specifically on why science cannot find its way into policy more easily [10-18]. There is convergence among authors in pointing that, in order to influence environmental policy implementation, scientific knowledge should (a) address questions and demands identified by the wider community; (b) be framed within an interdisciplinary context; (c) be designed or at least produced in coordination with the users; and (d) be communicated in a way that can be understood and appropriated by them [13,15,19-22]. But sometimes all these conditions are not enough to ensure effective incorporation of scientific findings into environmental policy implementation. The main arguments as to why this happens can be summarized, perhaps simplistically, in two broad categories.

The first one, called "Information Deficit Model" (also known as "Deficit Model" or "Science Deficit Model", it is probably the most popular approach among scientists [2326]. It proposes that the reason for the poor translation of scientific findings into policy implementation is the lack of public understanding of science. The science-policy interface 
is seen as a two-player game where scientists have to produce and deliver sound scientific knowledge to policy makers who, in turn, will produce appropriate policies. The model follows a linear and unidirectional trajectory from the identification of relevant research questions by scientists to the adoption of recommendations based on its results, in the form of favourable changes in policy. The public is assumed to be "deficient", in the sense that their mistrust in scientific contributions is attributed to their ignorance of the underpinning science [24]. The lack of impact of science on policy is usually seen as scientists' failure to address relevant research questions and/or properly convey the message to politicians, or as the incapacity of policy makers to "read" the scientific message in an appropriate manner. According to the critical view of Lawton [23], this model assumes that, were policy makers more adequately briefed with relevant, policy-oriented scientific findings, "correct" policies will follow. In other words, it is basically a technical-communicational problem.

The second category or arguments, called "Power Dynamics Model", conceives the science-policy interface as a multidirectional and iterative process where power relationships play a critical role. Keeley and Scoones [10] suggest that policy making and implementation consist of a broad course of action where many actors and types of knowledge are involved and where decisions and actions evolve iteratively over time, rather than linearly. Instead of been the instrumental execution of rational decisions, it is an inherently political process, in which scientific knowledge is only one element. This model identifies four major interrelated components [10,11]:
a) Discourses and narratives: What is the dominant 'policy narrative'? How is it framed through science, research, or other types of knowledge? What are the alternative narratives and how are they grounded? Narratives are socially constructed, developed, and defended storylines, which do not necessarily need to be based on sound empirical knowledge to be considered legitimate. Policy narratives intend to show in which way policy should proceed and are part of the political arena where ideologies and interests are ever conflicting and negotiated upon [27]. Different narratives are not equally important or compelling, or count with similar levels of approval or legitimacy. Issues of power, value, political interests, types of knowledge and conjunctural aspects make some of them more appealing than others. When they consolidate, they become "common sense" and are normalized by institutions, interest groups and governments. If hegemonic, they become part of people's everyday practices and may be reinforced through time.

b) Actors and networks: Who is involved and how they are connected? Which are the main alliances and disputes among social actors? How social networks evolve along time?

c) Politics and interests: What are the prevailing power dynamics and power relationships? What are the power trajectories of actors and networks advocating for different policies? Policies are frequently seen as objective, value-free, based on the results of the best 
available knowledge, and responding to a wider societal interest. However, they are often the result of the interests of particular groups.

d) Policy spaces: To what extent are policy makers restricted in their decision-making by forces such as the power of a dominant actor network or dominant narratives? Within this context, "moments of policy space" may emerge allowing alternative perspectives to challenge dominant discourses and political positions.

For this model, the process involves not just two main actors, but a whole network of them, with different trajectories and interests, and representing different alliances and conflicts. Scientific knowledge is just one of the various factors that influence policy in the context of the socio-economic disputes and political struggles that take place in society $[10,28]$. implementation is eminently a political process.

\section{Drawing upon a case study, here we analyze the science-policy interface and discuss why} interdisciplinary, policy-relevant, co-produced scientific knowledge fails to influence policy making. We focus on the discussion of a provincial law aiming at protecting the native forests of the Gran Chaco Region in the Province of Córdoba (Argentina). We conclude that the Power Dynamics Model best explains the failure of policy-relevant science to influence policy implementation in our case study. More generally, we suggest that this model provides useful insight into the role of scientists in environmental policy implementation.

\section{A case study - forest protection in the Gran Chaco}

In Argentina, Chaco forests are threatened by the rapid expansion of industrial agriculture, in particular intensive annual-crop cultivation and semi-intensive cattle ranching (Box 1). In order to regulate this land use change process, in 2007 the Argentine National Parliament passed a law (Law 26331) ${ }^{1}$ aimed at protecting the remaining native forests in the country, as well as the livelihoods of campesinos and indigenous peoples traditionally making a living from them. It defines three main conservation categories (red, yellow and green) for areas with very high, intermediate, and low conservation value, respectively, and prescribes the activities allowed in each category. It explicitly promotes the restoration, conservation, and sustainable use of native forests, as well as protecting the ecosystem services that they provide to society. This law is a general framework from which each province is expected to produce its own law for following a strict protocol concerning procedural as well as technical aspects. Specifically, each of the provincial laws should be the product of a

\footnotetext{
${ }^{1}$ Full text of the Law 26331 available from http://infoleg.mecon.gov.ar/infolegInternet/anexos/135000139999/136125/norma.htm
} 
participatory process involving a wide spectrum of social actors, whose representatives should meet in an ad-hoc commission (Comisión para el Ordenamiento Territorial del Bosque Nativo, or COTBN). It also mandates a series of regional public hearings open to all citizens.

The government of Córdoba Province appointed its Commission in 2009 in order to discuss its provincial law. The participants, coming from a number of organizations, soon converged into two interest networks of social actors: the pro-environment network (PEN), and the pro-agribusiness network (PAN). They had contrasting views about what to do with the remaining forests, how to approach agriculture and -ultimately- what model of development to follow (see next section, in particular Table 1). The PEN gathered different social actors and individuals sharing broadly similar ecological and social interest but with heterogeneous degree of experience in the political arena, and very limited experience in working together. In contrast, the PAN was a group that had been working together for decades and had extensive experience in influencing policy-making. The economic and political interests and visions of these groups were differentially reflected in the Provincial Parliament: the PEN position was supported by a minority of legislators, while that of PAN was close to the views of the ruling political party and other political parties with majority in the Parliament.

Soon after the Commission was formed internal disputes arose and most PAN representatives walked away claiming that the Commission was controlled by environmental fundamentalists [29]. The Commission continued operating, this time with a clear PEN majority. The Provincial Parliament opened a discussion space coordinated by a ruling party legislator, in which the Commission met periodically with the ecology working group of the Parliament in order to analyze different proposals.

A number of natural and social scientists offered their research findings and expertise to the Commission, with different degrees of involvement at various stages of the process, contributing to the PEN or PAN arguments. Some of these scientists -ecologists, geographers, rural sociologists, agronomists, economists, lawyers, medics- provided the technical foundation to the bill that the Commission was charged to submit to the Provincial Parliament. Some other researchers -agronomists, economists, lawyersprovided technical support to the PAN's position outside the formal work of the Commission. The two national public universities of Córdoba Province (Universidad Nacional de Córdoba and Universidad Nacional de Río Cuarto) officially supported the PEN position and the Commission's bill.

The PAN's position was that native vegetation other than the best preserved forests was agronomically not productive enough, because the native herbaceous layer does not provide enough forage, and the closed shrub layer hinders cattle access. The proposed management 
actions were (a) the partial or total removal of the woody vegetation using a roller chopper, in order to release resources (mostly light) for the herbaceous layer, and facilitate livestock mobility through it; and (b) the sowing of exotic high-yield pastures such as Cenchrus ciliaris and Panicum maximum to boost cattle carrying capacity [30-32] .

Our interdisciplinary research team was invited to participate in the public hearings and in the meeting space between the Commission and the Provincial Parliament, on the basis of what was explicitly considered relevant research findings. We had developed a novel interdisciplinary conceptual framework and methods focusing on the links between biodiversity, ecosystem services, social heterogeneity and land use change [33]. Key stakeholders actively participated in the research. Our findings, presented in detail in Ref. [34] and summarized in Box 1, showed how different social actors perceived, valued and appropriated ecosystem services and how they associated them to major ecosystem types in the Chaco region. A clear picture emerged in terms of the number and quality of ecosystem services provided by different ecosystem types and their importance to stakeholders. This, in convergence with the findings by several other research groups working inside and outside the Commission, had implications for the conservation value -and thus the need to protect or sustainably manage- different ecosystem types in the context of the new Provincial Law. The old-growth lowland Chaco forest was highly valued by all sectors of society (Box 1); in addition it now represents a minuscule proportion of the area of the Province [35-37], mostly under governmental ownership and/or protection. Therefore there was no major disagreement over granting them the maximum protection status contemplated by the National Law. The focus of the dispute between PEN and PAN were the secondary forests and species-rich shrublands. These are the most extended ecosystem types in the region [34,37,38], and are mostly in private hands [39]. Critically, they provide key ecosystem services underpinning campesinos' livelihood strategies, as well as being valued by other rural and urban social actors as sources of a wide range of regulating, provisioning and cultural ecosystem services $[34,40]$. There is also evidence of their capacity to regenerate, at least to some degree, under appropriate management [38,41-43]. In addition, the expansion of modern agribusiness generates stark conflicts between the two ways of farming often resulting in campesinos put out of business and forced to emigrate $[39,44,45]$. Therefore, if no legislation prevented the expansion of industrial agriculture over Chaco native ecosystems, there would be significant negative consequences for ecological integrity and for ecosystem services valued by a range of social actors, as well as the loss of campesinos' livelihoods and their likely expulsion from the land. On the other hand, for the few members of the PAN who continued participating in the discussions, these ecosystem types symbolize ecological degradation and social backwardness [44], which modern agribusiness has the capacity to replace with more productive farming systems, that could fuel local and regional economies [46], including better social services 
223 in cities and towns. Both positions were clearly communicated to the wider public and well covered by the press. ${ }^{2}$

Two bills reached the Provincial Parliament between June and July 2010. One was produced by the Commission following the official process described above, as prescribed by National Law 26331, and it was never debated in Parliament. It was instead replaced by another bill, representing the PAN interests, less than 24 hours in advance of the session, and was debated and passed on 10 August 2010 by 52 votes against $12^{3}$. As well as being

231 in stark contradiction with state-of-the-art ecological and environmental thinking and 232 empirical evidence in the field, the new Provincial Law 9814/2010 ${ }^{4}$ did not follow the 233 participatory process mandated by the National Law [29] and favored one economically 234 powerful social group over all others stakeholder groups involved. The new legislation 235 allows the conversion of the complex mosaic of ecosystems present in the region into 236 industrial agriculture, provided a certain administrative process is followed. After the 237 approval, an action for protection of constitutional rights was presented to the Supreme 238 Court of Justice by Universidad Nacional de Río Cuarto on behalf of PEN, and was 239 dismissed on formal grounds. After this political defeat, the PEN lost momentum and 240 agency capacity and stopped generating actions as a group.

\section{The Provincial Law process in the light of two models of the science-policy interface}

Can the two models described in the introduction shed light on the process of discussion

247 "ticked all the boxes", including availability to policy makers in an appropriate and timely

\footnotetext{
${ }^{2}$ Sandra Díaz - La Voz del Interior - 30 March 2010 http://www.lavoz.com.ar/content/los-fachinales-conservan-el-60-del-carbono-de-cordoba COTBN - La Voz del Interior - 27 July 2010

http://www.lavoz.com.ar/ciudadanos/se-movilizaron-para-exigir-la-sancion-de-la-ley-de-bosques La Voz del Interior - 21 July 2010 http://www.lavoz.com.ar/ciudadanos/otra-vez-hay-riesgo-de-que-no-se-apruebe-la-ley-de-bosques-0 McHardy (President of Sociedad Rural Argentina -Jesús María, Province of Córdoba in the newspaper La Mañana de Córdoba -12 April 2010). Sociedad Rural Argentina is an association of large-scale farmers and ranchers, founded in 1868 .

http://www.Imcordoba.com.ar/nota/9684_ley-de-bosques-fuertes-criticas-del-campo-entidades-aseguran-nohaber-sido-escuchadas

${ }^{3}$ At that moment the two main political parties (Unión por Córdoba and Unión Cívica Radical) supported PAN's interests and together controlled 48 out of the 70 parliament seats. The third political force (Frente Cívico y Social) had 11 legislators of which six voted in favour of PAN's position and five in favour of the PEN's. The remaining 11 legislators, belonging to 10 minority political forces, were mostly aligned with PEN's bill (seven votes).

${ }^{4}$ Full text of the Law 9814/2010 available from http://aplicaciones.ambiente.gob.ar/archivos/web/OrdTerrBN/file/leyes\%20prov/C\%C3\%B3rdoba\%20\%20Ley\%20N\%C2\%BA\%209814.pdf
} 
manner, effective communication to, and appropriation by the public- should have been effectively incorporated into policy. Therefore, this model does not appear to illuminate the process or offer obvious ways to improve action in the future.

In order to analyse the process from the perspective of the Power Dynamics Model, in which scientific input is just one of the elements to be considered in a complex socialpolitical interplay, we dissected the process using the four categories proposed by Ref. [10]: actors and networks, discourse and narratives, politics and interests, and policy spaces (Table 1). It is clear from the table that what was at stake went well beyond environmental issues. Two networks of social actors clashed, representing contrasting narratives, political trajectories and interests. Environmental groups allied with campesinos organizations, despite representing a wider section of society and having presented a project that was procedurally more appropriate and with a narrative based on wider scientific evidence, failed to impose their position. Agribusiness farmers allied with agroindustry and conservative political parties imposed their interests over the mandate of a pre-existing national law. This expresses a historical power alliance between economic and political powers that uses the institutional framework of the State in their own benefit, disregarding wider environmental and social costs [29]. Power struggles between similar networks, resulting in similar outcomes, have been observed in the case of the laws for the protection of native forests introduced by other provinces [47-50]. The active involvement of a wide range of social actors and networks, including major scientific organizations widely respected by society at large, had minimum influence in the Provincial Law. Power asymmetries -based on historical trajectories as well as on present policy spaces- were simply too large to allow the participatory process to have a strong imprint on policy implementation [29]. The passing of the Córdoba Provincial Law for the Protection of Native Forests is therefore well explained by the Power Dynamics Model: relevant socialecological science failed to be incorporated into environmental policy implementation because the latter is not simply "information-limited". Rather, it represents the net outcome of a much wider interplay of socio-political factors.

\section{Conclusions and wider implications}

The case study shows the limitations of scientific knowledge to effectively influence environmental policy implementation. This is not a "delivery problem" where the scientific findings fail to reach the appropriate policy maker, nor is a "communication/translation problem" where the message is not graspable by target audiences. Rather, policy-making is a highly contested, non-linear and multi-sectoral field where the interplay of institutions, subjectivities, values, interests, power relationships, as well as knowledge, plays a role; science is just one element in this wider framework. Therefore, the expectation of smooth unidirectional "research lab-policy implementation-positive change" is arguably narrow- 
minded as well as unrealistic. This might present a discouraging picture to some researchers interested in influencing the environmental science-policy interface. If policy implementation is the result of a much wider and intricate societal dynamics, and the outcome ultimately depends on sheer balance of power, what would then be the role of scientific knowledge in the process?

298

Far from denying the importance of science in environmental policy, our work suggests that its role is crucial, but things are considerably more complicated than "just" doing relevant science in frequent consultation with stakeholders and making findings available in a wellpackaged form. While scientific production requires only following the internal rules of good practice, engaging in policy implementation unavoidably involves additional rules and considerations $[10,13,15,23]$.

Is it possible to anticipate how likely is a piece of scientific knowledge to be incorporated into environmental policy implementation? Using the categories of analysis of the Power Dynamics Model, and on the basis of the present case study and other cases in point, below we propose four broad conditions to consider in anticipating successful incorporation: the sectors of society that are likely to benefit or lose, the ability to convey and communicate compelling narratives, the integration with wider social-actor networks, and the emergence of socio-political windows of opportunity. In all cases, the scientific finding is assumed (equally) internally solid, directly relevant to the environmental issue at hand, and available in accessible format to the stakeholders involved.

a) Prospective winners and losers (pertaining politics and interests according to the Power Dynamics Model categories). Scientific knowledge is more likely to be incorporated into policy implementation when it aligns with the interests of the sectors that concentrate the larger shares of political power in society, either on their own or through alliances. For example, in our case study, social-ecological scientific recommendations about Chaco forests antagonized the economic interests of sectors with high political power. Other recommendations, such as municipal regulations to sort and recycle household waste in the province, have been implemented and adopted more easily.

b) Compelling storylines (discourses and narratives). Scientific findings that are encapsulated in compelling, widely-communicated storylines, and are well understood and appropriated by society, are more likely to be integrated into policy. Policy narratives simplify reality by offering straightforward explanations of what the problem is, what the solution should be, and which would be the likely consequences of not doing what needs to be done. How much social support can be rallied behind a narrative depends on its internal consistency, but also on external factors, such as resonance with cultural tradition, alignment with the dominant "common sense" discourse, and even fashion and lifestyle trends. The dominance of any narrative, however strong, is not permanent, and its 
legitimacy is eventually contested. Scientists in association with other social actors can help developing consistent narratives backed by state-of-the-art interdisciplinary evidence. They can also unveil weaknesses or contradictions in narratives that are not based on sound or updated scientific knowledge. For instance, in relation to our case study, prevailing narratives have turned into common sense the idea that the replacement of native forests by industrial agriculture will lead to development and well-being for society as a whole. The work of scientists (e.g. Refs.[35-39,51-56]) has supported with empirical evidence an alternative narrative in which native forests provide multiple societal benefits, and have questioned the net society-wide wellbeing outcome of industrial agriculture (Box 1, Table 1). Compelling narratives are inextricably linked to communication strategies. Effective communication is indispensable -although, as argued earlier, not sufficient- for science to influence policy. Available means of communication include interviews, documentary and fictional pieces in the mass media, social networking websites, blogs, brochures, public events, artistic performances and exhibitions, and meetings with policy-makers. There is a wealth of information and examples coming from communication and education sciences, as well as from the advertising industry, on how to best convey a given message to different audiences. As a general rule, storylines that are short, clearly reasoned, attractively presented, surprising, and relate to the experience of the audience are more likely to be adopted.

c) Seating at the table (actors and networks). Scientific knowledge is more likely to be incorporated into policy implementation when it has been appropriated by, and is well integrated into the agenda of a wide range of social actors with active representation in the negotiation process. Scientists can share their findings with groups of interest such as civilsociety and governmental organizations, and thus contribute to integrate their products into their agendas. Such social actors often have more experience on advocacy activities, better knowledge about administrative procedures, and a more fluent communication with the press than researchers. Examples of how scientists can enhance the chances of their products finding their ways into policy implementation include carrying out on-demand primary research or assessments of existing evidence, producing timely policy briefs on issues considered strategic by these stakeholders, and getting actively involved in scientific advisory panels with enough agency capacity.

d) Windows of opportunity (policy spaces). Scientific knowledge that can timely contribute to create or take advantage of social-political windows of opportunity should have higher chances to be incorporated into policy implementation. Policy making is often, but not always, ruled by dominant narratives, economic and political structures, or by the interests of the most powerful players. Power balance and social actor conflicts and alliances are constantly being renegotiated and recreated. Unexpected turns can occur, brought about by conjunctural factors, shifts in relative power, new alliances, or the interests of powerful individuals, allowing the emergence of new, more favorable, policy 
spaces [10]. These moments of favorable policy space allow alternative narratives to gain momentum. For example, in the process leading to the Córdoba Provincial Law the ProEnvironment Network were clearly defeated. However, the National Law 26331 mandates the re-discussion of provincial laws every five years in order to update conservation priorities. The research team that carried out the study of Box 1 is also involved in this new stage opened by the provincial government in 2014, with representation in the Native Woodlands Executive Unit (Unidad Ejecutora de Bosques Nativos) recently appointed by

\footnotetext{
${ }^{5}$ As a result of societal concerns on the negative impacts of industrial agriculture on people's health, several municipalities are forbidding the use of pesticides in 500-1500 $\mathrm{m}$ strips around towns. For instance, the ban for the use of pesticides recently approved by the Municipality of Monte Maíz, a rural town located at the heart of the agricultural region of the Province of Cordoba. See http://www.lmcordoba.com.ar/nota/210010_ediles-aprobaron-crear-una-zona-de-resguardo-ambiental-enmonte-maiz

${ }^{6}$ Laudato $S i$ ' is available at http://w2.vatican.va/content/francesco/en/encyclicals/documents/papafrancesco_20150524_enciclica-laudato-si.html

For media coverage of recent drought and flood events see: http://www.lavoz.com.ar/regionales/sierraschicas-poca-agua-y-mas-protestas; and http://www.lavoz.com.ar/ciudadanos/cientificos-de-la-unc-explicanlas-causas-de-las-inundaciones-en-sierras-chicas
} 
404 Acknowledgements

405

406 This article is a contribution of Núcleo DiverSus, supported by Consejo Nacional de

407 Investigaciones Científicas y Técnicas (CONICET), Universidad Nacional de Córdoba, 408 FONCyT (PICT 554), SECyT (Res. 203/14), PIP 1145-201101-0040, and the Inter409 American Institute for Global Change Research (IAI) CRN 2015 and SGP-CRA2015, 410 which were supported by the US National Science Foundation (grants GEO-0452325 and 411 GEO-1138881). 


\section{Box 1. Ecological change and socio-ecological conflicts in the Gran Chaco}

With about 1.3 million $\mathrm{km}^{2}$, the Gran Chaco is the second largest natural biome in Latin America, after the Amazon forests [62]. In the lowlands at its southern extreme, in Argentina, the natural vegetation is an open xerophytic forest dominated by Aspidosperma quebracho-blanco and Prosopis flexuosa, alternating with patches of scrubland $[35,37,38,63]$. Historically, it has been occupied by campesinos and aboriginal peoples carrying out a wide range of non-intensive agricultural and hunting and gathering practices, coexisting with large-scale cattle ranches. During the last decades, a combination of technological, economic and political factors, together with a wetter climate, have fuelled the replacement of the natural vegetation by annual crops, particularly soy, and semiintensive cattle ranching [35,36,43,54,64]. As a result of these accelerated land use changes, a series of deep social transformations and consequent social and ecological conflicts have emerged among different social actors [39,53,55].

Drawing upon the interdisciplinary conceptual framework and multi-stakeholder participatory methodology proposed by Díaz et al. [33], Cáceres et al. [34] studied how different social actors with stakes in the Córdoba Province portion of the Gran Chaco perceived and valued different ecosystem services, and how they associated them with different components of biodiversity, ecological attributes, and ecosystem types. The valuation consisted of a quantitative-qualitative social valuation scoring that circumvented the problems associated with monetary valuation in comparing the perspectives of different social actors with contrasting worldviews and shares of power. Six major ecosystem types and five relevant social actors were identified (columns and rows in Figure 1, respectively). Individual perceptions on ecosystems services were surveyed through 163 individual interviews, and the links between ecosystem services and the ability of ecosystems types to provide them were discussed in seven focus groups with stakeholders.

Although all social actors perceived all ecosystem types as multifunctional, they showed markedly different perceptions of and interests in the ES provided by them. The main research findings are summarized in Fig. 1, where each cell contains the ecosystem services that each social actor associated to each of the six ecosystem types. Subsistence farmers perceived and used nearly all the identified ecosystem services and relied mostly on those ones provided by the most pristine ecosystem types. Extension officers and policy makers also identified many ecosystem services linked with the different ecosystem types. However, large farmers and cattle ranchers recognized a dependency on only a small number of ecosystem services. Therefore, the rapid expansion of agribusiness occurring in this region is a threat to a large number of ecosystem services considered valuable by a wide range of SA. Overall, the most pristine ecosystem types (i.e., primary forests, secondary forests, and species-rich shrublands) were the most valued by social actors. "Fodder trees and shrubs for goats" and "wild fruits for human and animal consumption" 
454 were the most important ecosystem services for subsistence farmers. "Water retention and 455 regulation by soil and vegetation" and "soil fertility for crops and pastures" were prioritized 456 by large farmers; while "fodder grasses and herbs for cattle and horses" and "soil fertility 457 for crops and pastures" were the most important for cattle ranchers. Unlike capitalized 458 farmers, subsistence farmers, have a heavy reliance on the ecosystem services provided by 459 native forests and shrublands. Ecosystem services valued by urban and remote societies 460 such as "climate regulation for humans and domestic animals", "carbon sequestration", and 461 "water retention and regulation by soil and vegetation" are also best provided by the most 462 pristine ecosystems. For full description of methods, results and implications, see Ref. [34].

463

464

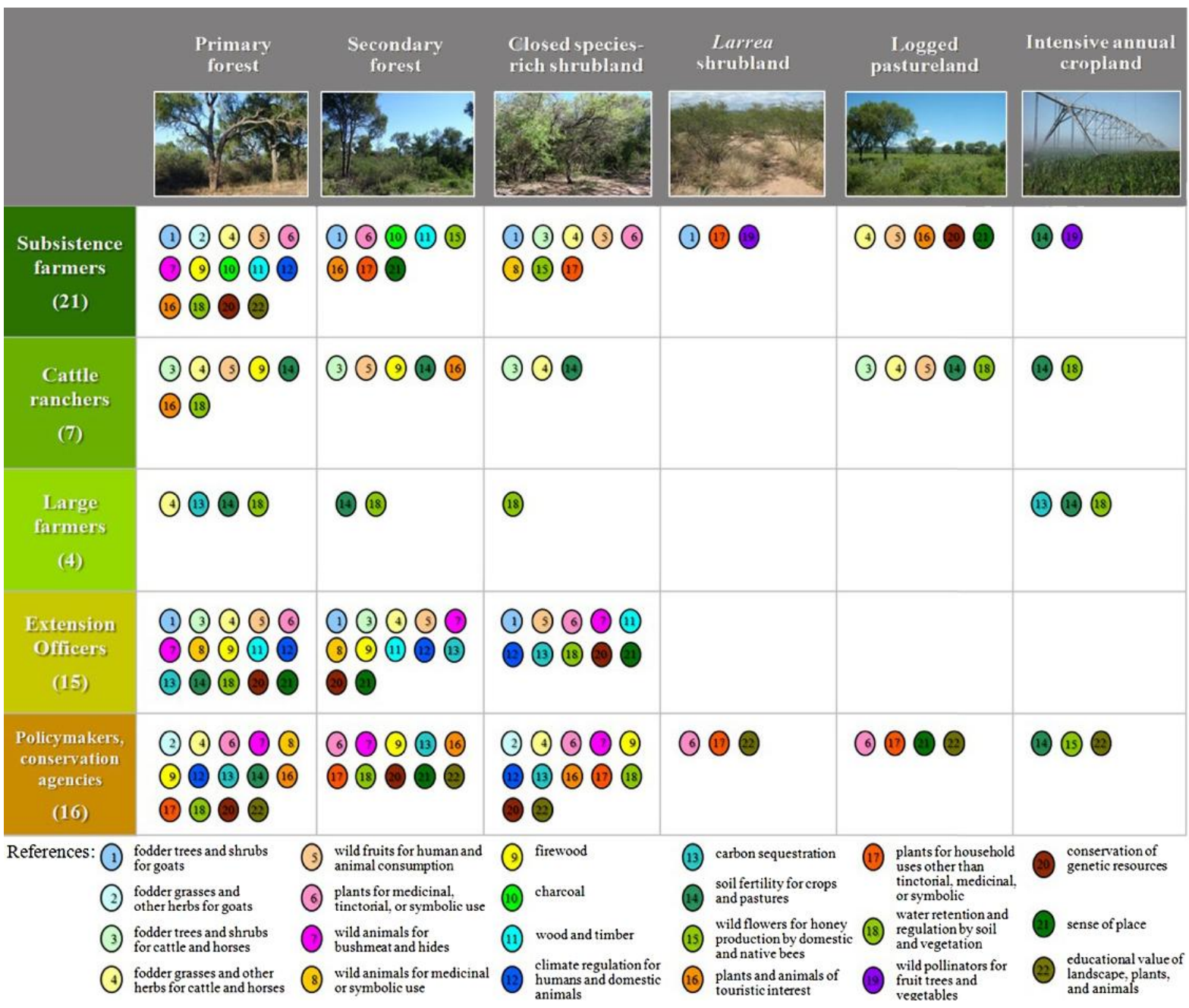

Figure 1. Ecosystem services perceived as important by social actors and their link with the ecosystem types that are able to supply them, based on the results of seven stakeholder focus groups. The number between brackets in the first column represents the total number of ecosystem services perceived by each social actor. Reproduced from Ref. [34]. 
References

1. Stratton JA: Changing Role of Science and Technology. Nature 1964, 203:455-457. International Journal of Science Education 2006, 28:1267-1287.

3. Likens GE: The role of science in decision making: does evidence-based science drive environmental policy? Frontiers in Ecology and the Environment 2010, 8:e1-e9.

4. Rosenberg AA, Halpern M, Shulman S, Wexler C, Phartiyal P: Reinvigorating the role of science in democracy. 2013.

5. Lalor BM, Hickey GM: Strengthening the role of science in the environmental decision-making processes of Executive government. Organization \& Environment 2014:1086026614525641.

6. Kates RW, Clark WC, Corell R, Hall JM, Jaeger CC, Lowe I, McCarthy JJ, Schellnhuber HJ, Bolin B, Dickson NM, et al.: Environment and development: Sustainability science. Science 2001, 292:641-642.

7. Clark WC, Dickson NM: Sustainability science: the emerging research program. Proceedings of the national academy of sciences 2003, 100:8059-8061.

8. Webersik C, Wilson C: Achieving environmental sustainability and growth in Africa: the role of science, technology and innovation. Sustainable Development 2009, 17:400-413.

9. Brandt P, Ernst A, Gralla F, Luederitz C, Lang DJ, Newig J, Reinert F, Abson DJ, von Wehrden H: A review of transdisciplinary research in sustainability science. Ecological Economics 2013, 92:1-15.

10. Keeley J, Scoones I: Understanding environmental policy processes: Cases from Africa. 2003.

11. Wolmer W, Keeley J, Leach M, Mehta L, Scoones I, Waldman L: Understanding Policy processes: A review of IDS research on the environment. Institute of Development Studies, University of Sussex 2006.

12. Pellini A, Dolores M, Alicias NTTH, Bachtiar PP: Technically sound and politically achievable? A taxonomy of knowledge types and their influence on governance in three South-East Asian countries. Background Note. London: ODI 2012.

13. **Kamelarczyk KBF, Gamborg C: Spanning boundaries: Science-policy interaction in developing countries-The Zambian REDD+ process case. Environmental Development 2014, 10:1-15.

Investigates science-policy interactions in forestry in developing countries, and suggests new opportunities to strengthen the links between science and policy.

14. Udovyk O: Models of science-policy interaction: Exploring approaches to Bisphenol A management in the EU. Science of the Total Environment 2014, 485:23-30.

15. Armitage D, de Loë RC, Morris M, Edwards TWD, Gerlak AK, Hall RI, Huitema D, Ison R, Livingstone D, MacDonald G, et al.: Science-policy processes for transboundary water governance. In Ambio. Edited by; 2015. 
16. López-Rodríguez MD, Castro AJ, Castro H, Jorreto S, Cabello J: Science-policy interface for addressing environmental problems in arid Spain. Environmental Science \& Policy 2015, 50:1-14.

17. Sawyer RHaK: Public Engagement on Genetically Modified Organisms: When Science and Citizens Connect. 2015.

18. *Valente A, Castellani T, Larsen M, Aro AR: Models and visions of science-policy interaction: Remarks from a Delphi study in Italy. Science and Public Policy 2015, 42:228-241.

Analyzes different models of science-policy interaction, implicitly or explicitly adopted by stakeholders -researchers, politicians, doctors and journalists.

19. National Academy of Sciences: Facilitating Interdisciplinary Research. 2004.

20. Lövbrand E: Co-producing European climate science and policy: a cautionary note on the making of useful knowledge. Science and public policy 2011, 38:225-236.

21. *Bik HM, Dove ADM, Goldstein MC, Helm RR, MacPherson R, Martini K, Warneke A, McClain C: Ten Simple Rules for Effective Online Outreach. 2015.

Provides guidance on how scientists can utilize new media tools and describe ten rules for conducting effective online outreach of scientific knowledge through social media.

22. Cooke N, Hilton M: Enhancing the Effectiveness of Team Science. 2015.

23. Lawton JH: Ecology, politics and policy. Journal of Applied Ecology 2007, 44:465474.

24. Sturgis $\mathrm{P}$, Allum N: Science in society: re-evaluating the deficit model of public attitudes. Public understanding of science 2004, 13:55-74.

25. Brown S: The new deficit model. Nature nanotechnology 2009, 4:609-611.

26. Ahteensuu M: Assumptions of the deficit model type of thinking: Ignorance, attitudes, and science communication in the debate on genetic engineering in agriculture. Journal of Agricultural and Environmental Ethics 2012, 25:295-313.

27. Shin H, Choi BD: Risk Perceptions in UK Climate Change and Energy Policy Narratives. Journal of Environmental Policy \& Planning 2015, 17:84-107.

28. Sumberg J, Thompson J, Woodhouse P: Why agronomy in the developing world has become contentious. Agriculture and Human Values 2013, 30:71-83.

29. Silvetti F, Soto GC, Caceres DM, Cabrol D: ¿ Por qué la Legislación no Protege a los Bosques Nativos de Argentina? Conflictos Socioambientales y Políticas Públicas en la Provincia de Córdoba. 2013.

30. Anriquez A., Albanesi A, Kunst C, Ledesma R, López C, Rodríguez Torresi A, J. G: Rolado de fachinales y calidad de suelos en el Chaco occidental, Argentina. Ciencia del Suelo 2005, 23.

31. Bonfante A: Control Mecánico de malezas arbustivas en pasturas subtropicales. In Manejo y Control del Renoval. Edited by Kunst C: CREA; 2006:144-147.

32. Felman I: Control Químico del Renoval. In Manejo y Control del Renoval. Edited by Kunst C: CREA; 2006:102-104.

33. Díaz S, Quétier F, Cáceres DM, Trainor SF, Pérez-Harguindeguy N, Bret-Harte MS, Finegan B, Peña-Claros M, Poorter L: Linking functional diversity and social actor strategies in a framework for interdisciplinary analysis of nature's benefits to society. Proceedings of the National Academy of Sciences 2011, 108:895-902. 
34. **Cáceres DM, Tapella E, Quétier F, Díaz S: The social value of biodiversity and ecosystem services from the perspectives of different social actors. Ecology and Society 2015, 20:62.

Drawing upon the framework proposed by Diaz et al. (2011), presents an interdisciplinary analysis of how social actors perceive, use and value the ecosystem services provided by different ecosystem types of central Argentina.

35. Zak MR, Cabido M, Hodgson JG: Do subtropical seasonal forests in the Gran Chaco, Argentina, have a future? Biological conservation 2004, 120:589-598. 36. Zak MR, Cabido M, Cáceres D, Díaz S: What drives accelerated land cover change in central Argentina? Synergistic consequences of climatic, socioeconomic, and technological factors. Environmental Management 2008, 42:181-189.

37. *Hoyos LE, Cingolani AM, Zak MR, Vaieretti MV, Gorla DE, Cabido MR: Deforestation and precipitation patterns in the arid Chaco forests of central Argentina. Applied Vegetation Science 2013, 16:260-271.

Analyses interactions between changing precipitation and land cover in the Southern extrme of the Chaco region during the $20^{\text {th }}$ century.

38. Cabido M, Zak M: Vegetación del Norte de Córdoba. Córdoba: Secretaría de Agricultura y Recursos Renovables de la Provincia de Córdoba \& Agencia Córdoba Ambiente; 1999.

39. *Cáceres DM: Accumulation by Dispossession and Socio-Environmental Conflicts Caused by the Expansion of Agribusiness in Argentina. Journal of Agrarian Change 2015, 15:116-147.

Discusses the main social-ecological conflicts arising both in the countryside and urban areas, as a result of the expansion of industrial agriculture over native Chaco forests in central Argentina.

40. Silvetti F: Una revisión conceptual sobre la relación entre campesinos y servicios ecosistémicos. Cuadernos de Desarrollo Rural 2011, 8:17-45.

41. Barchuck A, Campos E, Oviedo C, Díaz M: Supervivencia y crecimiento de plántulas de especies leñosas del Chaco Árido sometidas a remoción de la biomasa aérea. Ecología Austral 2006, 16:47-61.

42. Carranza C, Noe L, Merlo C, Ledesma M, Abril A: Efecto del tipo de desmonte sobre la descomposición de pastos nativos e introducidos en el Chaco Árido de la Argentina. Revista de Investigaciones Agropecuarias 2012, 30:97-107.

43. Karlin M, Karlin O, Coirini R, Reatti G, Zapata R: El Chaco Arido. Córdoba: Encuentro Grupo Editor; 2013.

44. Silvetti F: Trayectoria histórica de la territorialidad ganadera campesina en el Oeste de la Provincia de Córdoba, Argentina. Agricultura, Sociedad y Desarrollo 2012, 9:333-367.

45. Cáceres DM, Rodríguez-Bilella P: Acceso y apropiación del agua en comunidades rurales pobres de Argentina central: Transformaciones y conflictos. Economía, sociedad y territorio 2014, 14:359-395.

46. Pinto LH: . Problematizando el "debate ambiental" desde la hegemonía neoliberal en Argentina: notas sobre la experiencia del Movimiento Nacional Campesino Indígena (MNCI). In Historia, Política y Gestión Ambiental. Perspectivas y Debates. Edited by Zarrilli ASaA. Buenos Aires.: Imago Mundi; 2012:6-13. 47. Seghezzo L, Volante JN, Paruelo JM, Somma DJ, Buliubasich EC, Rodríguez HE, Gagnon S, Hufty M: Native forests and agriculture in Salta (Argentina): 
609

610

611

612

613

614

615

616

617

618

619

620

621

622

623

624

625

626

627

628

629

630

631

632

633

634

635

636

637

638

639

640

641

642

643

644

645

646

647

648

649

650

651

652

653

654

655

conflicting visions of development. The Journal of Environment \& Development 2011:1070496511416915.

48. García Collazo MA, Panizza A, Paruelo JM: Ordenamiento Territorial de Bosques Nativos: Resultados de la Zonificación realizada por provincias del Norte argentino. Ecología austral 2013, 23:97-107.

49. Jara CE: La dimensión ecológica de las luchas campesinas: Disputas en torno al Ordenamiento Territorial de los Bosques Nativos en Santiago del Estero. Trabajo y sociedad 2014:389-405.

50. Schmidt M: (Des) ordenamientos territoriales salteños. Una aproximación al contexto previo al Ordenamiento Territorial de Bosques Nativos en la provincia de Salta. Mundo agrario 2014, 15.

51. Iglesias M, Barchuk A, Grilli M: Carbon storage, community structure and canopy cover: A comparison along a precipitation gradient. . Forest Ecology and Management 2012, 265:218-229.

52. Conti G, Díaz S: Plant functional diversity and carbon storage-an empirical test in semi-arid forest ecosystems. Journal of Ecology 2013, 101:18-28.

53. Paolassi P, Krapovickas J, Gasparri NI: Deforestación, expansión agropecuaria y dinámica demográfica en el Chaco Seco Argentino durante la década de los noventa. Latin American Research Review 2012, 47:35-63.

54. Gasparri NI, Baldi G: Regional patterns and controls of biomass in semi-arid woodlands: lessons from the Northern Argentina Dry Chaco. Regional Environmental Change 2013, 13:1131-1144.

55. Pengue W: En Carne Viva. Deforestación y Desarrollo Insustentable en el Gran Chaco. Fronteras 2013, 12.

56. Conti G, Pérez-Harguindeguy N, Quétier F, Gorné L, Jaureguiberry P, Bertone G, Enrico L, Cuchietti A, Díaz S: Large changes in carbon storage under different land-use regimes in subtropical seasonally dry forests of southern South America. Agriculture, Ecosystems \& Environment 2014, 197:68-76.

57. Berger M, Ortega F: Poblaciones expuestas a agrotóxicos: autoorganización ciudadana en la defensa de la vida y la salud, Ciudad de Córdoba, Argentina. Physis (Rio J.) 2010, 20:119-143.

58. Carrizo Sineiro C, Berger M: Citizens' Rights and Environmental Genocide. Environmental Justice 2012, 5:105-110.

59. Seveso M: Derechos humanos; oídos sordos a reclamos de los pueblos. Theomai 2014, 30.

60. Guyton KZ, Loomis D, Grosse Y, El Ghissassi F, Benbrahim-Tallaa L, Guha N, Scoccianti C, Mattock H, Straif K: Carcinogenicity of tetrachlorvinphos, parathion, malathion, diazinon, and glyphosate. The Lancet Oncology 2015, 16:490-491.

61. IPCC: Summary for policymakers. In Climate Change 2014: Impacts, Adaptation, and Vulnerability. Edited by. Cambridge, UK and New York: Cambridge University Press; 2014:1-32.

62. Bucher EH, Huszar PC: Sustainable management of the Gran Chaco of South America: Ecological promise and economic constraints. Journal of Environmental Management 1999, 57:99-108.

63. Britos A, Barchuck A: Land use and land cover changes in two Arid Chaco sites, northwest of Córdoba Province, Argentina. Agriscientia 2008, XXV:97-110. 
656 64. Cáceres D, Soto G, Ferrer G, Silvetti F, Bisio C: La expansión de la agricultura 657 industrial en Argentina Central. Su impacto en las estrategias campesinas. $658 \quad$ Cuadernos de desarrollo rural 2010, 7:91-119.

660 
Figure 1

\begin{tabular}{|c|c|c|c|c|c|c|}
\hline & $\begin{array}{l}\text { Old-growih } \\
\text { woodland } \\
\text { ny }\end{array}$ & $\begin{array}{l}\text { Secondary } \\
\text { woodland } \\
\text { 3. }\end{array}$ & $\begin{array}{l}\text { Mrimed } \\
\text { shrubland } \\
\text { (6) } \\
\end{array}$ & 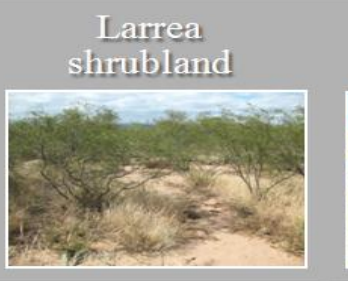 & 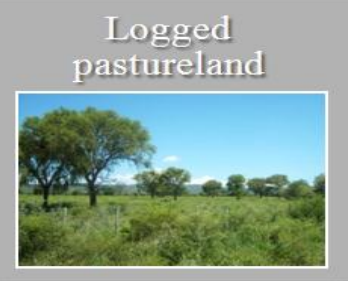 & $\begin{array}{l}\text { Intensive annual } \\
\text { cropland }\end{array}$ \\
\hline $\begin{array}{l}\text { Subsistence } \\
\text { farmers } \\
\text { (21) }\end{array}$ & 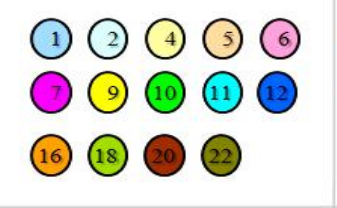 & 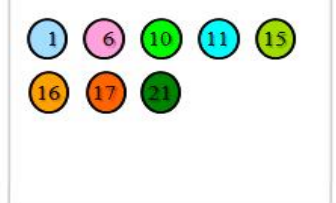 & 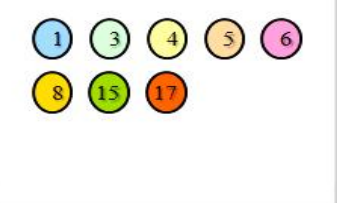 & (1) (1) (1) (-) & (ㄱ) (ㄱ) (16) (2) (2) & (14) (1) \\
\hline $\begin{array}{l}\text { Cattle } \\
\text { ranchers } \\
\text { (7) }\end{array}$ & $\begin{array}{l}\text { (3) (7) (3) (9) (14) } \\
\text { (16) (18) }\end{array}$ & (3) (3) (-) (1) (16) & (3) (3) (3) & & 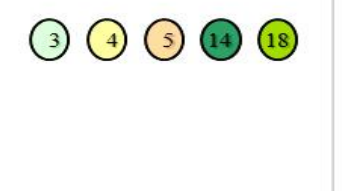 & (27) (18) \\
\hline $\begin{array}{l}\text { Large } \\
\text { farmers } \\
\text { (4) }\end{array}$ & (4) (13) (14) (18) & (17) (18) & (18) & & & (13) (14) (18) \\
\hline $\begin{array}{l}\text { Extension } \\
\text { Officers } \\
\text { (15) }\end{array}$ & 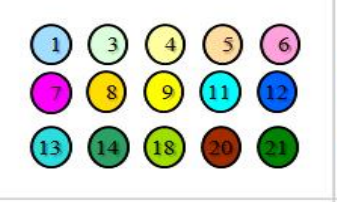 & 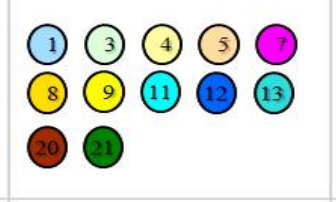 & 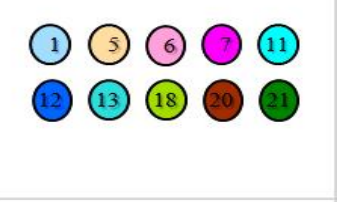 & & & \\
\hline $\begin{array}{l}\text { Policy makers, } \\
\text { conservation } \\
\text { agencies } \\
\text { (16) }\end{array}$ & 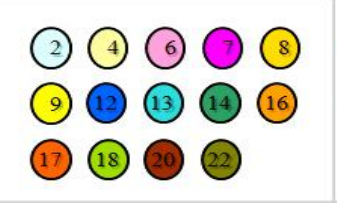 & 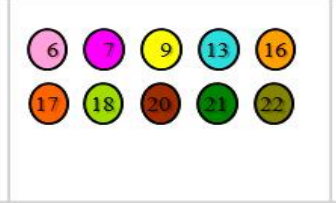 & 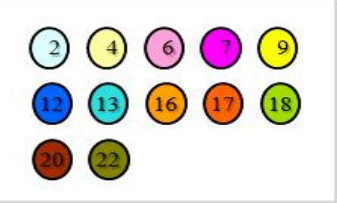 & (ㄱ) (11) (2) & 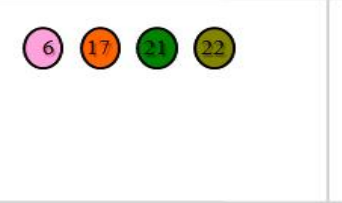 & (14) (13) (2) \\
\hline $\begin{array}{r}\text { References: (1) } \\
\text { (2) } \\
\text { (3) } \\
\text { (4) }\end{array}$ & 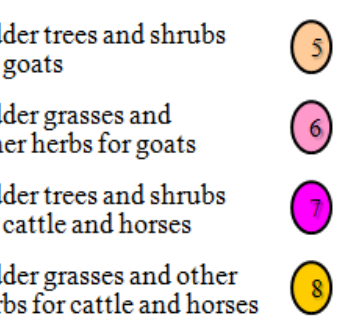 & $\begin{array}{l}\text { wild fruits for human and } \\
\text { animal consumption } \\
\text { plants for medicinal, } \\
\text { tinctorial or symbolic use } \\
\text { wild animals for } \\
\text { bushmeat and hides } \\
\text { wild animals for medicinal } \\
\text { or symbolic use }\end{array}$ & $\begin{array}{l}\text { (9) firewood } \\
\text { (10) charcoal } \\
\text { (11) wood and timber } \\
\text { (12) climate regulation for } \\
\text { humimans and domestic } \\
\text { anisals }\end{array}$ & $\begin{array}{l}\text { (13) carbon sequestration } \\
\text { soil fertility for crops } \\
\text { (14) and pastures } \\
\text { (15) wild flowers for honey } \\
\text { poductionby domesti } \\
\text { and native bees } \\
\text { (16) plants and animals of } \\
\text { touristicintinterest }\end{array}$ & 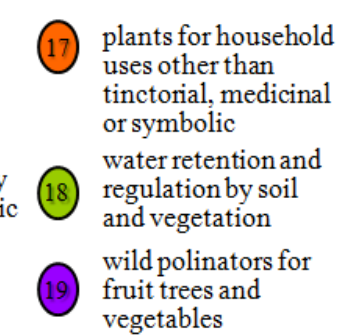 & $\begin{array}{l}\text { (20) } \begin{array}{l}\text { conservation of } \\
\text { genetic resources }\end{array} \\
\text { (21) sense of place } \\
\text { (22) educational value of } \\
\text { landscape, plants and } \\
\text { animals }\end{array}$ \\
\hline
\end{tabular}


Table 1: A description of two contrasting perspectives involved in the discussion of the Córdoba Provincial Law for the Protection of Native Forests (Law 9814/2010), following the categories suggested by Refs. [11,12]; see the Introduction for explanation of each category.

\begin{tabular}{|c|c|c|}
\hline & Pro-Agribusiness Network & Pro-Environmental Network \\
\hline $\begin{array}{l}\text { Policy } \\
\text { narratives }\end{array}$ & $\begin{array}{l}\text { Argentina has an enormous potential for grain production and } \\
\text { export. Its modern agriculture is bound to occupy an important role } \\
\text { as a global food and energy provider. Pampean lands have been } \\
\text { fully put into production long ago, therefore agriculture has to } \\
\text { expand over new, non-Pampean regions in order to meet growing } \\
\text { global demands. Vast areas in these regions are already degraded } \\
\text { and therefore of little value. Radical environmental groups and } \\
\text { short-sighted environmental legislation are putting obstacles to } \\
\text { agricultural expansion. This is retarding development, and } \\
\text { excluding backward sectors of society living in marginal areas from } \\
\text { progress and modernization. }\end{array}$ & $\begin{array}{l}\text { Argentina is a socially and environmentally heterogeneous country. } \\
\text { Chaco forests provide a wide variety of ecosystem services, which } \\
\text { are essential for the livelihoods of campesinos, aboriginal peoples } \\
\text { and the rural poor. Urban and remote societies also benefit from } \\
\text { some of these ecosystem services. The expansion of industrial } \\
\text { agriculture is not the solution but part of the problem of poverty and } \\
\text { asymmetric development. Agroecology and other farming } \\
\text { approaches that foster sustainability have the ability to fulfill } \\
\text { societal demands while preserving the environment. }\end{array}$ \\
\hline $\begin{array}{l}\text { Actors and } \\
\text { networks }\end{array}$ & $\begin{array}{l}\text { Capitalised farmers' associations, agroindustry, scientists backing } \\
\text { agribusiness, ruling political party and other conservative } \\
\text { legislators. Alliance with deep historical roots between agribusiness } \\
\text { interests and the conservative provincial government and other } \\
\text { conservative parties. High lobbying power. }\end{array}$ & $\begin{array}{l}\text { Campesinos' organizations, grassroots groups and organizations, } \\
\text { NGOs, social and environmental scientists, left-wing and centre-left } \\
\text { legislators. Network mostly newly built to participate in the } \\
\text { discussion of the Provincial Law. Low lobbying capacity. }\end{array}$ \\
\hline $\begin{array}{l}\text { Politics } \\
\text { and } \\
\text { interests }\end{array}$ & $\begin{array}{l}\text { National and international interests linked to the production, } \\
\text { commercialization, industrial manufacture, and financing of } \\
\text { agricultural commodities. They promote policies that foster } \\
\text { economic freedom and relax environmental regulations and } \\
\text { safeguards. }\end{array}$ & $\begin{array}{l}\text { Provincial and national interests sided with environmental groups } \\
\text { and grassroots organizations defending ecological integrity and } \\
\text { approaches to farming that do not jeopardize the sources of income } \\
\text { of less-advantaged rural social actors. They advocate for policies } \\
\text { compatible with a more equitable access to ecosystem services and } \\
\text { a more ecologically sustainable and socially inclusive path to } \\
\text { development. They promote strong social and health safeguards, } \\
\text { Some of them promote strong environmental and biodiversity- } \\
\text { conservation regulations. }\end{array}$ \\
\hline $\begin{array}{l}\text { Policy } \\
\text { spaces }\end{array}$ & $\begin{array}{l}\text { (a) International markets show a steady demand for agricultural } \\
\text { commodities produced by Argentina; (b) Argentina's 2001 } \\
\text { economic crisis and external debt require the hard currency that }\end{array}$ & $\begin{array}{l}\text { (a) There is a growing concern about the negative impacts of } \\
\text { industrial agriculture on people's health; and (b) recent extreme- } \\
\text { weather events (i.e., rains well above average, followed by floods) }\end{array}$ \\
\hline
\end{tabular}


have produced extensive damages in the Province of Córdoba and have raised people's awareness about the buffering effects of native forests. 